\title{
Occurrence of Sheathed Flagella in Campylobacter cinaedi and Campylobacter fennelliae
}

\author{
Y.-H. HAN ${ }^{1}$ R. M. SMIBERT, ${ }^{2}$ AND N. R. KRIEG ${ }^{1 *}$ \\ Microbiology and Immunology Section, Department of Biology, ${ }^{1}$ and Department of Anaerobic Microbiology, ${ }^{2}$ \\ Virginia Polytechnic Institute and State University, Blacksburg, Virginia 24061
}

\begin{abstract}
Campylobacter cinaedi and Campylobacter fennelliae possess sheathed flagella, a feature which, among organisms currently classified as campylobacters, had been associated previously only with Campylobacter pylori. No other Campylobacter or Wolinella species possesses sheathed flagella. This feature helps to characterize the phylogenetic group that includes $C$. pylori, $C$. fennelliae, and $C$. cinaedi; however, Wolinella succinogenes, the fourth member of this group, does not possess sheathed flagella.
\end{abstract}

Comparisons of the partial $16 \mathrm{~S}$ ribosomal ribonucleic acid (rRNA) sequences of various members currently listed in the genus Campylobacter have indicated that Campylobacter pylori should be excluded from the genus Campylobacter and that this species is instead related to Wolinella succinogenes $(8,11-13)$. Studies by Thompson et al. (13) indicated that Campylobacter cinaedi and Campylobacter fennelliae also belong to the same rRNA similarity group (rRNA group II) that contains $C$. pylori and $W$. succinogenes; this rRNA group was considered to represent a separate genus. Regardless of whether this group represents a genus or a higher taxon, it is difficult at present to arrive at a suitable phenotypic definition of the group that distinguishes it from rRNA group I, which contains the true campylobacters and four putative anaerobes $(11,13)$. Thompson et al. (13) noted that one of the initial problems with rRNA group II (viz., the putative anaerobic nature of $W$. succinogenes) could be eliminated because, like $C$. pylori, $C$. cinaedi, and $C$. fennelliae, $W$. succinogenes is oxidase positive and, as shown by Wolin et al. (14), is able to respire with oxygen as a terminal electron acceptor under microaerobic conditions $\left(\leq 2 \% \mathrm{O}_{2}\right)$. The microaerophilic nature of $W$. succinogenes makes its inclusion with $C$. pylori, $C$. cinaedi, and $C$. fennelliae more feasible in phenotypic terms.

In the past, one phenotypic feature that seemed to be unique to $C$. pylori was the occurrence of sheathed flagella $(6,7)$. Sheathed flagella have also been reported in Campylobacter pylori subsp. mustelae (4) and other gastric spiral bacteria isolated from various animals, as summarized by Marshall (9). Sheathed flagella are relatively uncommon among bacteria and thus have taxonomic significance; e.g., among gram-negative bacteria they are characteristic of the genus Vibrio (1), the genus Bdellovibrio (2), Pseudomonas andropogonis (synonym, 'Pseudomonas stitzolobii') (5), and two Alteromonas species $(3,10)$. Because of the relatedness of $C$. pylori to $C$. cinaedi, $C$. fennelliae, and $W$. succinogenes, we thought that these latter species might also possess sheathed flagella.

Cells of several strains were negatively stained by using the method described by Goodwin et al. (7). The rRNA

\footnotetext{
* Corresponding author.
}

group I $(11,13)$ strains examined included Campylobacter coli ATCC $33569^{\mathrm{T}}$ ( $\mathrm{T}=$ type strain), Campylobacter jejuni ATCC $33560^{\mathrm{T}}$, Campylobacter fetus subsp. fetus ATCC $27374^{\mathrm{T}}$, Campylobacter fetus subsp. venerealis ATCC $19438^{\mathrm{T}}$, Campylobacter laridis NCTC $11352^{\mathrm{T}}$, Campylobacter mucosalis NCTC $11000^{\mathrm{T}}$, Campylobacter concisus ATCC $33237^{\mathrm{T}}$, Campylobacter hyointestinalis ATCC $35217^{\mathrm{T}}$, Campylobacter sputorum biovar sputorum strain ATCC $35980^{\mathrm{T}}$, "Campylobacter upsaliensis" CG-1, Wolinella recta ATCC $33238^{\mathrm{T}}$, and Wolinella curva ATCC $35224^{\mathrm{T}}$. (In addition, Bacteroides ureolyticus ATCC $33387^{\mathrm{T}}$ and Bacteroides gracilis ATCC $33236^{\mathrm{T}}$, which are also members of group I [11], were examined and were found to lack flagella.) The rRNA group II $(8,11-13)$ strains examined included $C$. cinaedi ATCC $35683^{\mathrm{T}}$, C. fennelliae ATCC $35684^{\mathrm{T}}$, and $W$. succinogenes ATCC $29543^{\mathrm{T}}$. The rRNA group III (13) strains examined included Campylobacter cryaerophila NCTC $11885^{\mathrm{T}}$ and Campylobacter nitrofigilis ATCC $33309^{\mathrm{T}}$.

Of the above-mentioned strains, only the $C$. cinaedi strain (Fig. 1A and B) and the C. fennelliae strain (Fig. 1C and D) exhibited sheathed flagella. Some C. fennelliae cells also had flagella with terminal bulbs resembling those described for $P$. andropogonis (5) and C. pylori $(6,7)$, but no terminal bulbs were observed in the $C$. cinaedi preparations. It is interesting that $W$. succinogenes, the fourth member of rRNA group II, showed no evidence of sheathed flagella, despite an exhaustive search. Our studies also indicated that $C$. $\mathrm{ci}^{-}$ naedi, $C$. fennelliae, and W. succinogenes cells possess a single flagellum at one or both poles, whereas $C$. pylori has been reported to possess multiple polar flagella $(6,7)$ and appears to be unique among the campylobacter-like organisms in this feature.

We regard the fact that three of the four species of rRNA group II had sheathed flagella and that the members of rRNA groups I and III did not as taxonomically significant. This finding also suggests that further comparisons of the members of group II may reveal other underlying phenotypic similarities that may help to define this phylogenetic group in phenotypic terms. For instance, we have found that all four group II species possess hydrogenase activity, as indicated by $\mathrm{H}_{2}$-dependent reduction of benzyl viologen. However, 

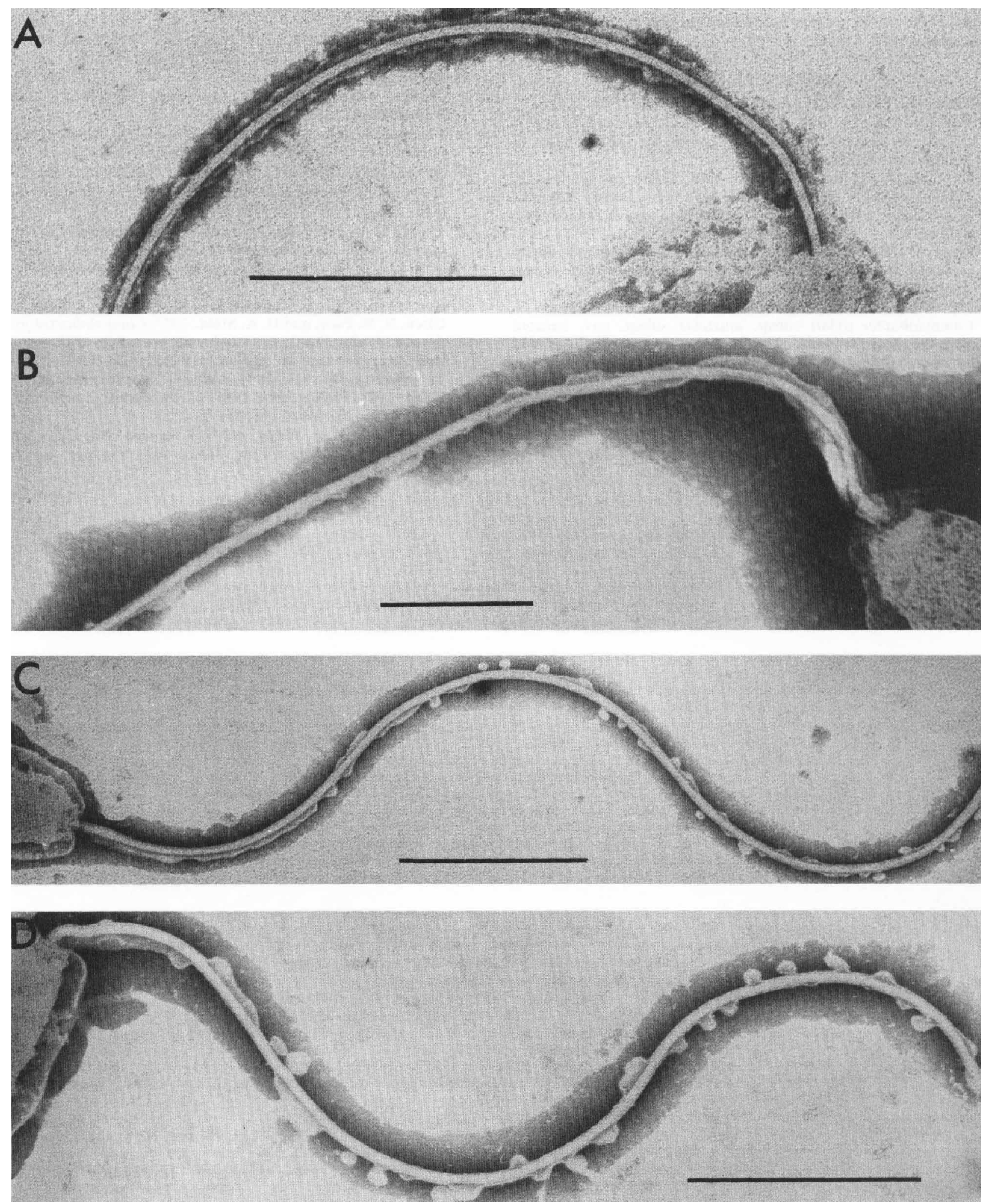

FIG. 1. Electron micrographs of C. cinaedi (A and B) and C. fennelliae (C and D) showing the occurrence of a flagellar sheath. The preparations were negatively stained with phosphotungstate. Bars $=0.5 \mu \mathrm{m}$. 
this feature is not unique to rRNA group II; some species in rRNA group I also exhibit hydrogenase activity.

This work was supported in part by project 2127020 from the Commonwealth of Virginia.

\section{LITERATURE CITED}

1. Baumann, P., A. L. Furniss, and J. V. Lee. 1984. Genus I. Vibrio, p. 518-538. In N. R. Krieg and J. G. Holt (ed.), Bergey's manual of systematic bacteriology, vol. 1. The Williams \& Wilkins Co., Baltimore.

2. Burnham, J. C., and S. F. Conti. 1984. Genus Bdellovibrio, p. 118-124. In N. R. Krieg and J. G. Holt (ed.), Bergey's manual of systematic bacteriology, vol. 1. The Williams \& Wilkins Co., Baltimore.

3. Enger, Ø., H. Nygaard, M. Solberg, G. Schei, J. Nielsen, and I. Dundas. 1987. Characterization of Alteromonas denitrificans sp. nov. Int. J. Syst. Bacteriol. 37:416-421.

4. Fox, J. G., N. S. Taylor, P. Edmonds, and D. J. Brenner. 1988. Campylobacter pylori subsp. mustelae subsp. nov. isolated from the gastric mucosa of ferrets (Mustela putorius furo), and an emended description of Campylobacter pylori. Int. J. Syst. Bacteriol. 38:367-370.

5. Fuerst, J. A., and A. C. Hayward. 1969. The sheathed flagellum of Pseudomonas stizolobii. J. Gen. Microbiol. 58:239-245.

6. Geis, G., H. Leying, S. Suerbaum, U. Mal, and W. Opferkuch. 1989. Ultrastructure and chemical analysis of Campylobacter pylori flagella. J. Clin. Microbiol. 27:436-441.
7. Goodwin, C. S., R. K. McCulloch, J. A. Armstrong, and S. E. Wee. 1985. Unusual cellular fatty acids and distinctive ultrastructure in a new spiral bacterium (Campylobacter pyloridis) from the human gastric mucosa. J. Med. Microbiol. 19:257-267.

8. Lau, P. P., B. DeBrunner-Vossbrinck, B. Dunn, K. Miotto, M. T. MacDonnell, D. M. Rollins, C. J. Pillidge, R. B. Hespell, R. R. Colwell, M. L. Sogin, and G. E. Fox. 1987. Phylogenetic diversity and position of the genus Campylobacter. Syst. Appl. Microbiol. 9:231-238.

9. Marshall, B. J. 1989. Experimental models in vivo for Campylobacter pylori. Gastroenterol. Clin. Biol. 13:50B-52B.

10. Novick, N. J., and M. E. Tyler. 1985. Isolation and characterization of Alteromonas luteoviolacea strains with sheathed flagella. Int. J. Syst. Bacteriol. 35:111-113.

11. Paster, B. J., and F. E. Dewhirst. 1988. Phylogeny of campylobacters, wolinellas, Bacteroides gracilis, and Bacteroides ureolyticus by $16 \mathrm{~S}$ ribosomal ribonucleic acid sequencing. Int. J. Syst. Bacteriol. 38:56-62.

12. Romaniuk, P. J., B. Zoltowska, T. J. Trust, D. J. Lane, G. J. Olsen, N. R. Pace, and D. A. Stahl. 1987. Campylobacter pylori, the spiral bacterium associated with human gastritis, is not a true Campylobacter sp. J. Bacteriol. 169:2137-2141.

13. Thompson, L. M., III, R. M. Smibert, J. L. Johnson, and N. R. Krieg. 1988. Phylogenetic study of the genus Campylobacter. Int. J. Syst. Bacteriol. 38:190-200.

14. Wolin, M. J., E. A. Wolin, and N. J. Jacobs. 1961. Cytochromeproducing anaerobic vibrio, Vibrio succinogenes, sp. n. J. Bacteriol. 81:911-917. 